\title{
Pregnancy with neurofibromatosis type II: the enigma continues
}

\author{
Ankita Pandey*, Minakshi Tripathi, Simantini Bose, Balaji Jadhav, Y. S. Nandanwar
}

Department of Obstetrics \& Gynaecology, LTMMC\&GH, Sion, Mumbai, Maharashtra, India

\author{
Received: 11 March 2015 \\ Revised: 18 March 2015 \\ Accepted: 18 April 2015 \\ *Correspondence: \\ Dr. Ankita Pandey, \\ E-mail: sonamnrs86@gmail.com
}

Copyright: (C) the author(s), publisher and licensee Medip Academy. This is an open-access article distributed under the terms of the Creative Commons Attribution Non-Commercial License, which permits unrestricted non-commercial use, distribution, and reproduction in any medium, provided the original work is properly cited.

\begin{abstract}
Neurofibromatosis type II in pregnancy has variable presentations. The recurrence rate and bilaterality of $\mathrm{CP}$ angle tumour is very high. We present a case of bilateral schwanomma diagnosed in midpregnancy, for which patient was operated in second trimester and postpartum radiotherapy will now be given.
\end{abstract}

Keywords: Neurofibromatosis, Schwanomma, Autosomal dominant trait, Spinal anaesthesia

\section{INTRODUCTION}

Neurofibromatosis type II affects about 1 in every 40000 people without regard to sex or race. They are at high risk of developing tumours (Schwanomma) on both nerves to the ears. This nerve has two portions. Acoustic concerned with hearing and vestibular concerned with balance inputs to the brain. ${ }^{1}$ The early symptoms of Neurofibromatosis type II are dysfunction of these nerves- hearing loss, tinnitus (Acoustic) and problems of balance (Vestibular). These tumours are also called schwanomma as they arise from Schwann cells covering the nerve. However, they can arise from other cells as well like ependymoma and meningioma. Some patients of Neurofibromatosis type II can also present with special type of cataract called juvenile posterior sublenticular opacity. ${ }^{2,3}$

\section{CASE REPORT}

Mrs. ABC 26 years of age, married since 4 years, $\mathrm{G}_{2} \mathrm{P}_{1} \mathrm{IUFD}_{1}$, previous caesarean section, at present 38.5 weeks period of gestation, known case of Neurofibromatosis type II, with bilateral cerebellopontine angle schwanomma operated in 2014.
Patient is a known case of neurofibromatosis type II and was diagnosed to have bilateral cerebellopontine angle schwanomma in April 2014. She underwent right retrosigmoid craniotomy with excision of right $\mathrm{CP}$ angle in $9^{\text {th }}$ October 2014. She then complained of swelling and pain on operated site on $30^{\text {th }}$ October 2014. Diagnosed to have pseudomeningocoele, which had settled subsequently following lumbar puncture done 3 times.

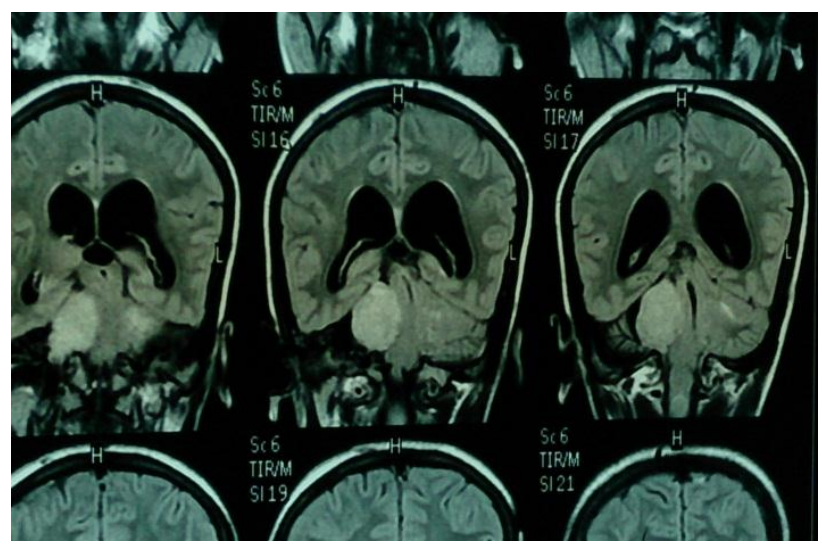

Figure 1: MRI brain in coronal view showing tumour at cerebello-pontine angle). 


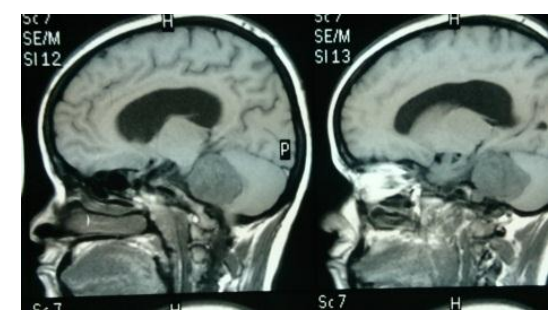

Figure 2: Tumour at cerebello-pontine angle displacing midbrain structures anteriorly in sagittal section of MRI brain.

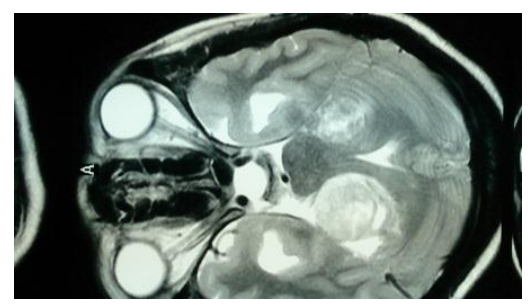

Figure 3: Transverse section of MRI brain showing tumour at right $\mathrm{CP}$ angle.

Patient was also diagnosed to have deranged blood sugars in October 2014. Started on inj. insulin 8 units thrice a day. Presently she is also taking tab. levipril (500 mg) OD. Patient had significant family history as her mother had expired of brain tumour (details not known). Patient was vitally stable when came to the hospital and was taken for emergency caesarean section in view of scar tenderness in labour. Perinatal outcome was healthy female child of $3.5 \mathrm{~kg}$. Postoperative course was uneventful.

\section{DISCUSSION}

Two major treatment options available for neurofibromatosis type II are surgery and radiotherapy. Though they do require surgery once in the lifetime, it is not without risk as the tumour lies very close to nerves, it is likely to damage the delicate nerve. There are additional risks associated with anaesthesia as well. Radiation therapy also is associated with risks and benefits which must be outweighed vis a vis. ${ }^{4}$ Neurofibromatosis type II is a genetic disease that is passed from parent to child during conception. All persons with Neurofibromatosis type II have 50-50 risk of affecting the children. Disorders such as neurofibromatosis type II which affect both sexes equally and are transmitted to $50 \%$ of their children are termed as autosomal dominant. Exact segment of DNA that causes neurofibromatosis type II has been identified on chromosome 22 and can be identified and isolated with FISH technique or hybridization. ${ }^{5-7}$

\section{CONCLUSION}

The outcome of baby will be evident only in due course of time. As the tumours, even in genetically predisposed patients appear at a later age, in late teens. The only way to confirm if child would be affected in future is to subject the baby to chromosomal evaluation for segmental DNA analysis during antenatal period. However, in the present case scenario, it was not possible as the woman had presented for antenatal registration in almost $7^{\text {th }}$ month of gestation when time limit for terminating pregnancy was exceeded well in advance. In the case presented here, only way to find out if child will be affected is either subject them to chromosomal study or subject the child to audiometric evaluation.

Hence, the enigma still continues as whether the baby will be affected or not, as there is no conclusive way to diagnose whether the baby has the defective gene.

\section{Funding: No funding sources \\ Conflict of interest: None declared \\ Ethical approval: Not required}

\section{REFERENCES}

1. Children's Tumour Foundation, New York. Latest news, 2015. Available at: www.ctf.org.

2. Weissman A, Jakobi P, Zaidise I, Drugan A. Neurofibromatosis and pregnancy. An update. J Reprod Med. 1993;38(11):890-6.

3. Torpy JM, Burke AE, Glass RM. Neurofibromatosis. JAMA. 2009;302:2170.

4. Babovic-Vuksamovic. (Expert Opinion). Neurofibromatosis. Mayo clinic. Rochester, Minn., 2012. Available at: http://www.mayoclinic.org/diseasesconditions/neurofibromatosis/multimedia/con20027728. Accessed 26 November 2012.

5. Nebesio TD, Ming W, Chen S, Clegg T, Yuan J, Yang Y, et al. Neurofibromin deficient Schwann cells have increased lysophosphatidic acid dependent survival and migration - implications for increased neurofibroma during pregnancy. Glia. 2007;55(5):527-36.

6. Ferner RE. The neurofibromatoses. Practical Neurol. 2010;10:82.

7. Dashe JF, Gilchrist JM. Overview of schwannomatosis, 2012. Available at: http://www.uptodate.com/index. Accessed 12 October 2012.

DOI: $10.18203 / 2320-1770 . i j r \operatorname{cog} 20150113$

Cite this article as: Pandey $A$, Tripathi $M$, Bose $S$, Jadhav B, Nandanwar YS. Pregnancy with neurofibromatosis type II: the enigma continues. Int $\mathbf{J}$ Reprod Contracept Obstet Gynecol 2015;4:869-70. 